\title{
RAB13 regulates Sertoli cell permeability barrier dynamics through protein kinase A
}

\author{
Wenhui Su' and Xinchun Liu ${ }^{2}$ \\ ${ }^{1}$ Department of Biochemistry and Molecular Biology, Basic Medical College, ${ }^{2}$ Department of Orthopedics, \\ First Affiliated Hospital, China Medical University, 92 Beier Road, Heping District, Shenyang 110001, China
}

Correspondence should be addressed to W Su

Email

whsu@mail.cmu.edu.cn

\begin{abstract}
In mammalian testes, the blood-testis barrier (BTB), created by specialized junctions between Sertoli cells near the basement membrane of the seminiferous epithelium, provides an indispensable immune-privileged microenvironment for spermatid development. However, the BTB must experience restructuring during the epithelial cycle to facilitate the transit of preleptotene spermatocytes upon the testosterone-induced new TJ fibrils forming behind these cells, which is intimately related to the extensive dynamics of junction protein complexes between Sertoli cells. As key regulators of protein traffic, Rab GTPases participate in delivery of proteins between distinct cellular sites and cross talk with proteins that constitute tight junction and adherens junction. Using primarily cultured Sertoli cells in vitro with an established tight junction permeability barrier that mimics the BTB in vivo, RAB13 was shown to decrease during the testosterone-induced TJ integrity enhancement, accompanied with an increment in protein kinase A (PKA) activity. Furthermore, knockdown of Rab13 was found to resemble the effect of testosterone on Sertoli cell TJ permeability by reinforcing filamentous actin and occludin distribution at the cell-cell interface and promoting the direct interaction between ZO-1 and occludin. Interestingly, the effects of testosterone and Rab13 knockdown on Sertoli cell epithelium were revealed to be antagonized by PKA activity inhibition. In summary, RAB13 serves as a regulatory component in the assembly and restructuring of the TJ fibrils between adjacent Sertoli cells.
\end{abstract}
Key Words
- RAB13
- Sertoli cell
- blood-testis barrier
- tight junction
protein kinase A

Journal of Molecular

Endocrinology

(2013) 50, 305-318

\section{Introduction}

In mammals, the blood-testis barrier (BTB) that divides the seminiferous epithelium into the basal and the adluminal (apical) compartment provides an independent environment for the development of meiosis I/II and postmeiotic spermatid in the apical part, segregating it from the basal part and the systematic circulation (Cheng \& Mruk 2010, 2012). This separation serves as an 'immune barrier' by avoiding, at least in part, the production of antibodies against the germ cell origin antigens expressed transiently during spermatogenesis. As the spermatogonia and the preleptotene spermatocytes reside closely to the basement edge of the seminiferous epithelium, the BTB must undergo extensive restructuring during the epithelial cycle, though it is one of the tightest blood-tissue barriers, to facilitate the transit of preleptotene spermatocytes into the apical compartment at stage VIII (Russell 1977, Cheng et al. 2011b). This process is mediated by the establishment of new tight junction fibrils below the traversing spermatocytes before the disruption of the old ones above the traversing spermatocytes (Cheng \& Mruk 2010, 2012).

Published by Bioscientifica Ltd. 
Thus, zygotene spermatocytes can differentiate into diplotene spermatocytes and prepare for meiosis without compromising the immunological barrier function of the BTB (Cheng \& Mruk 2010). Recent studies have demonstrated that integrity and dynamics of the BTB as a unique ultrastructure in the testis are conferred by coexisting junctions between Sertoli cells, namely tight junction (TJ), basal ectoplasmic specialization (ES; a testis-specific adherens junction type that also exists at the Sertoligerm cell interface as 'apical ES'), gap junction (GJ), and desmosome (Cheng et al. 2011a,b). Multiple physiological factors and biochemical molecules have been shown to participate in the regulation of BTB dynamics, such as cytokines (i.e. tumor necrosis factor $\alpha$ (TNF $\alpha$ (TNF)), and transforming growth factor $\beta 3$ (TGF $\beta 3$ (TGFB3)); Lui et al. 2001, Li et al. 2006, Xia et al. 2006), steroids (i.e. testosterone; Yan et al. 2008), actin-binding proteins (i.e. epidermal growth factor pathway substrate 8 (EPS8), actin-related protein 3 (ARP3 (ACTR3)), drebrin E, filamin A, etc.) (Lie et al. 2009, 2010a, Li et al. 2011, Su et al. 2012a), polarity proteins (i.e. PAR3/6, CDC42, scribble protein complex, etc.; Wong et al. 2008, 2010, Su et al. 2012b), and non-receptor protein tyrosine kinases (i.e. c-Yes, focal adhesion kinase (FAK); Xiao et al. 2011, Lie et al. 2012), whereas the underlying mechanisms by which these molecules regulate BTB still remain elusive.

During epithelial morphogenesis, the actin cytoskeleton substantially contributes to maintain TJ integrity (Madara et al. 1986, 1992, Balda et al. 1993), but the regulatory pathways that associate actin skeleton to TJ assembly still need to be elucidated. In the seminiferous epithelium, filamentous actin (F-actin) bundles at the Sertoli cell interface were found to lie perpendicular to the Sertoli cell plasma membrane and sandwiched between the cisternae of endoplasmic reticulum and the apposing Sertoli cell membrane (Vogl et al. 2008, Cheng \& Mruk 2010, 2012). This unique arrangement of F-actin bundles at the BTB confers its remarkable adhesive strength, which was quantified to be even stronger than desmosome at the Sertoli-pre-step 8 spermatid interface, one of the strongest anchoring junctions (Wolski et al. 2005, Green \& Simpson 2007, Green et al. 2010). In the past decades, small GTPases such as Rho/Rac were found to participate in the reorganization of F-actin and paracellular permeability in mammalian epithelia (Takaishi et al. 1997, Benais-Pont et al. 2003). Rab proteins (i.e. RAB3B, RAB13, and RAB8 (RAB8A)), another small GTPase subfamily that belongs to the Ras superfamily, are localized at the cell-cell interface in epithelial cells (Huber et al. 1993, Weber et al. 1994, Zahraoui et al. 1994) and have been revealed to be involved in multiple cellular events like endocytic and exocytic processes (Schimmoller et al. 1998, Chavrier \& Goud 1999), vesicle movement (Echard et al. 1998, Nielsen et al. 1999, White et al. 1999), and actin organization during the regulation of epithelial barrier function (Peranen et al. 1996). Among these Rab proteins, RAB13 has been shown to play a crucial role in structures and functions of TJs in polarized epithelial cells by mediating protein transportation to distinct membrane domains (Schimmoller et al. 1998, Takai et al. 2001, Pfeffer 2007). In Madin-Darby canine kidney (MDCK) cells, the active form of RAB13 was revealed to inhibit protein kinase A (PKA)dependent phosphorylation and perturb TJ recruitment of the actin remodeling protein, namely vasodilator-stimulated phosphoprotein (VASP; Kohler et al. 2004). In the testis, RAB13 was found to interact directly with two putative actin-binding proteins, vinculin and espin, and function in ES dynamics at the Sertoli-germ cell interface (Mruk \& Lau 2009). Herein, we investigated the involvement of RAB13 in Sertoli cell BTB function and the possible pathway by which it regulates the permeability of Sertoli cell TJ barrier.

\section{Materials and methods}

\section{Animals and antibodies}

Twenty-day-old male Sprague Dawley rats were obtained from the Department of Laboratory Animals, China Medical University (CMU). All experiments were performed at CMU in accordance to the NIH Guidelines for the Care and Use of Laboratory Animals. The protocol for animal handling and the treatment procedures were approved by the CMU Animal Care and Use Committee. Antibodies used for various experiments were commercially obtained from different vendors as described in Table 1. Reagents, unless otherwise specified, were from Sigma-Aldrich.

\section{Primary Sertoli cell cultures}

A widely used in vitro system was used in this study for isolation and culturing of Sertoli cells as described (Byers et al. 1986, Janecki et al. 1991a,b, 1992, Okanlawon \& Dym 1996, Grima et al. 1998, Lui et al. 2001, Mruk \& Cheng 2011). Sertoli cells were isolated from 20-day-old male Sprague Dawley rats (CMU) and cultured in serumfree DMEM/F12 (Gibco) at $35^{\circ} \mathrm{C}$ in a humidified atmosphere of $5 \% \mathrm{CO}_{2}$ with epidermal growth factor, insulin, transferrin, and bacitracin as described (Mruk \&

Published by Bioscientifica Ltd. 
Table 1 Antibodies used for different experiments in this report. Antibodies used herein were found to cross-react with the corresponding proteins in the rat as indicated by the manufacturers

\begin{tabular}{|c|c|c|c|c|c|c|c|}
\hline \multirow[b]{2}{*}{ Antibody } & \multirow[b]{2}{*}{ Catalog no. } & \multirow[b]{2}{*}{ Host } & \multirow[b]{2}{*}{ Vender } & \multirow[b]{2}{*}{ Conjugation } & \multicolumn{3}{|c|}{ Working dilution } \\
\hline & & & & & IB & IF & IP \\
\hline RAB13 & ab136414 & Rabbit & Abcam & - & $1: 1000$ & & $1: 50$ \\
\hline PKA $\alpha$ cat & sc-903 & Rabbit & Santa Cruz Biotechnology & - & $1: 500$ & & \\
\hline Occludin & $71-1500$ & Rabbit & Zymed/Invitrogen & - & $1: 250$ & $1: 50$ & \\
\hline JAM-A & sc-25629 & Rabbit & Santa Cruz Biotechnology & - & $1: 500$ & & \\
\hline ZO-1 & $61-7300$ & Rabbit & Zymed/Invitrogen & - & $1: 250$ & & $1: 40$ \\
\hline Actin & sc-1616 & Goat & Santa Cruz Biotechnology & - & $1: 500$ & & \\
\hline Rabbit IgG & sc-2370 & Bovine & Santa Cruz Biotechnology & HRP & $1: 3000$ & & \\
\hline Goat Ig $\vec{G}$ & sc-2768 & Rabbit & Santa Cruz Biotechnology & HRP & $1: 3000$ & & \\
\hline Rabbit lgG & A-31572 & Donkey & Invitrogen & Alexa Fluor 555 & & $1: 100$ & \\
\hline
\end{tabular}

IB, immunoblotting; IF, immunofluorescence microscopy; IP, immunoprecipitation.

Cheng 2011). It was noted that Sertoli cells from this age of rats were differentiated and stopped to divide and were morphologically and functionally similar to those isolated from adult rats (Orth 1982, Li et al. 2001). Specifically, isolated Sertoli cells were plated on Matrigel (BD Biosciences)-coated bicameral units, culture dishes, or microscopic coverslips at different cell densities depending on different use in the following experiments: i) Millicell-HA inserts (Millipore) at $1.2 \times 10^{6} / \mathrm{cm}^{2}$ for transepithelial electrical resistance (TER) measurement to assess the TJ-permeability barrier function of the Sertoli cells; ii) 12-well culture dishes at $0.5 \times 10^{6} / \mathrm{cm}^{2}$ for lysate preparation; and iii) coverslips at $0.05 \times 10^{6} / \mathrm{cm}^{2}$ for immunofluorescence analysis or F-actin staining. These cell densities for different studies were determined based on pilot experiments so that Sertoli cell TJ barrier function could be quantified, or sufficient proteins could be obtained for lysate preparation before immunoblot, or fluorescence microscopy could be performed to visualize protein distribution at the evenly arranged cell-cell interface. It has been confirmed by electron microscopy that a functional $\mathrm{TJ}$ barrier with ultrastructures of TJ, basal ES, GJ, and desmosome be established by Sertoli cells cultured on these Matrigel-coated utensils, mimicking the BTB in vivo (Lee \& Cheng 2003, Siu et al. 2005, Lie et al. $2010 b$ ). On day 2 after isolation, a hypotonic treatment with $10 \mathrm{mM}$ This (pH 7.4) at room temperature for $2 \mathrm{~min}$ was performed to lyse residual germ cells, so that these Sertoli cell cultures were with negligible contaminations of germ, Leydig, and myoid cells (Lee et al. 2004). For each experiment, triplicate culture units were used per time point and each experiment was repeated at least three times besides pilot experiments to determine the optimal experimental conditions.
Functional assessment of the Sertoli cell TJ permeability barrier in vitro

Using a digital resistance meter (DT-9208, Shanghai Jiajia, Shanghai, China), the TER across the Sertoli cell epithelial was measured and recorded daily (days 1-7) after isolation to assess the ability of an intact cell epithelium with functional $\mathrm{TJ}$ to resist current passage between the two electrodes placed respectively at the apical and the basal compartment of the bicameral units as described previously (Grima et al. 1998, Lui et al. 2001, Mruk \& Cheng 2011). For each time point, triplicate bicameral units were set and each experiment was repeated at least three times using different cell cultures.

\section{Treatment of testosterone and $\mathrm{H} 89$}

To assess the effects of testosterone on Sertoli cell TJ barrier assembly, the steady-state level of Rab13 expression, F-actin organization, and the role of PKA activity in these processes, Sertoli cells in some experiments were incubated with vehicle or testosterone $(0.2 \mu \mathrm{M})$ with or without $\mathrm{H} 89$ (30 $\mu \mathrm{M}$, a specific PKA inhibitor) in DMEM/F12 supplemented with growth factors from day 4 after isolation for TER assay or F-actin staining and terminated at different time points for immunoblot or PKA activity assay. The concentrations of testosterone and H89 used herein were selected based on earlier studies (Yan et al. 2008, Lie et al. 2010a, Su et al. 2012a). Sertoli cell cultures in triplicates were used for each time point and each experiment was repeated at least three times using different batches of Sertoli cells.

\section{Transfection of siRNA duplexes in cultured Sertoli cells}

Three siRNA duplexes specifically against rat Rab13 were designed and synthesized by GenePharma and one was

Published by Bioscientifica Ltd. 
selected after a preliminary experiment according to the knockdown efficiency. The selected sequence was subjected to BLAST to ensure no significant homology with other genes. The scrambled sequence was chemically synthesized by GenePharma as a non-targeting control. The siRNA sequences were as follows (sense and antisense respectively): Rab13, 5'-GAUGUAAGUGCUGUUGAAGtt$3^{\prime}$ and 5'-CUUCAACAGCACUUACATCtt-3'; scrambled control, 5'-AGGAGAUGUGAUAUUGGCUtt-3' and $5^{\prime}$ AGCCAAUAUCACAUCUCCUtt-3'.

Sertoli cells obtained from 20-day-old rats were cultured alone for 3 or 4 days before an intact cell epithelium was established. Thereafter, Sertoli cells cultured on different Matrigel-coated culture units were transfected with siRNA duplexes that specifically target Rab13 or with scrambled siRNA control using Lipofectamine 2000 reagent (Invitrogen). The siRNA and Lipofectamine 2000 reagents were mixed in Opti-MEM (Invitrogen) before transfection. The final transfection volume was $0.5 \mathrm{ml}$ DMEM/F12 (containing $3 \mu \mathrm{l}$ Lipofectamine 2000) in the apical chamber of the bicameral unit, which seated in a well of a 24-well plate containing another $0.5 \mathrm{ml}$ medium in the basal chamber, $1 \mathrm{ml}$ DMEM/F12 (containing $4 \mu \mathrm{l}$ Lipofectamine 2000) in a 12-well plate, or $2.5 \mathrm{ml}$ DMEM/F12 (containing $8 \mu \mathrm{l}$ Lipofectamine 2000) in a six-well plate with cells on coverslips. Based on pilot experiments for different cell densities with optimal phenotypes and without detectable cytotoxicity, the siRNA concentration used was selected at $150 \mathrm{nM}$ for TER measurement, $100 \mathrm{nM}$ for lysate preparation, and $80 \mathrm{nM}$ for immunofluorescence analysis or F-actin staining. After transfection for $24 \mathrm{~h}$, cells were rinsed and replenished with fresh DMEM/F12 and incubated for another $48 \mathrm{~h}$ before termination for lysate preparation or for another $24 \mathrm{~h}$ before fixation for immunofluorescence or F-actin staining. In groups to determine the role of PKA in regulation of Sertoli cell TJ barrier function after knockdown of Rab13, PKA inhibitor H89 $(30 \mu \mathrm{M})$ was added into the culture medium daily after transfection for TER assay, immunofluorescence, F-actin staining, and co-immunoprecipitation (Co-IP) experiments.

\section{Lysate preparation and immunoblot}

Nonidet P-40 IP lysis buffer $(50 \mathrm{mM}$ Tris, $150 \mathrm{mM} \mathrm{NaCl}$, 2 mM EGTA, 10\% glycerol (v/v), 1\% Nonidet P-40 (v/v), $2 \mathrm{mM}$ phenylmethylsulphonyl fluoride, $1 \mathrm{mM}$ sodium orthovanadate, $2 \mathrm{mM}$-ethylmaleimide, $1 \mu \mathrm{g} / \mathrm{ml}$ leupeptin, and $1 \mu \mathrm{g} / \mathrm{ml}$ aprotinin, $\mathrm{pH}$ 7.4) was used to lyse testes and Sertoli cells. Protein concentrations were detected using the protein assay kit (Bio-Rad Laboratories). Approximately $80 \mu \mathrm{g}$ protein from testis or $30 \mu \mathrm{g}$ protein from Sertoli cells were applied per lane and resolved by SDS-PAGE under reducing conditions for immunoblot with specific antibodies with actin serving as a loading control. Enhanced chemiluminescence was performed using a kit from Pierce Chemical Co. according to the manufacturer's protocols.

\section{Co-immunoprecipitation}

Co-IP was used to detect changes in protein-protein interactions in this study. A precleaning step was applied to avoid nonspecific IgG interaction. In brief, $2 \mu \mathrm{g}$ normal rabbit IgG were added to $500 \mu \mathrm{g}$ protein lysate from Sertoli cells and pre-incubated for $1 \mathrm{~h}$. After addition of $10 \mu$ protein A/G agarose (GenDEPOT) and incubation for another $1 \mathrm{~h}$, the lysate was concentrated at $4{ }^{\circ} \mathrm{C}$ and the supernatant was collected for subsequent steps. The supernatant was then incubated with $2 \mu \mathrm{g}$ normal rabbit IgG, which served as negative control, or $2 \mu \mathrm{g}$ anti-RAB13 or anti-zonula occluden-1 (ZO-1) antibody overnight at room temperature. Thereafter, $20 \mu \mathrm{l}$ protein A/G agarose beads were added to precipitate immunocomplexes, followed by gentle washing with IP lysis buffer. The immunocomplexes were at last extracted with an SDS-PAGE sample buffer at $100^{\circ} \mathrm{C}$ for 5 min before being subjected to SDS-PAGE resolving and immunoblot analysis.

\section{Immunofluorescence analysis and F-actin staining}

Sertoli cells cultured on Matrigel-coated coverslips at $0.05 \times 10^{6}$ cells $/ \mathrm{cm}^{2}$ were fixed with paraformaldehyde $(4 \%, \mathrm{w} / \mathrm{v}$ in PBS) at room temperature for $10 \mathrm{~min}$ before permeabilization with $0.1 \%$ Triton X-100 (v/v in PBS) for $4 \mathrm{~min}$. Then the Sertoli cells were treated with 5\% BSA (w/v in PBS) for $30 \mathrm{~min}$ for blocking before anti-occludin antibody (diluted in 1\% BSA at 1:50) was added and incubated overnight at room temperature. Secondary antibody conjugated with CY3-555 (red) was diluted in $1 \%$ BSA (1:150) and incubated at room temperature for $1 \mathrm{~h}$. For F-actin staining, Sertoli cells were incubated with Acti-stain 488 phalloidin (cytoskeleton) at the same time with the secondary antibody. Thereafter, the coverslips were mounted with Prolong Gold Antifade reagent with 4,6-diamidino-2-phenylindole (DAPI) (Invitrogen). Images were visualized with an Olympus BX60 fluorescence microscope (Olympus Optical Co.) and captured using a SpotRT digital camera (Diagnostic Instruments, Inc.) in TIFF format. Photoshop in Adobe Creative Suite Design

Published by Bioscientifica Ltd. 
Premium (version 3.0) was used to analyze and adjust for contrast/brightness and image overlay. We note that all micrograghs listed herein are representative images of at least three independent experiments using different batches of cells.

\section{PKA activity assay}

The activity of PKA was determined by the phosphorylation state of kemptide (Enzo Biochem), which is a specific synthetic substrate peptide (LRRASLG) of PKA, according to Grieco et al. (1994), with minor modification. In brief, fresh Sertoli cell lysate was diluted to $0.1 \mu \mathrm{g} / \mu \mathrm{l}$ with IP lysis buffer described earlier before $5 \mu \mathrm{l}$ were transferred to an Eppendorf tube. Then a total of $25 \mu \mathrm{l}$ reaction buffer $(54 \mathrm{mM} \beta$-glycerophosphate, $24 \mathrm{mM}$ 3-( $N$-morpholino)-propanesulfonic acid, $14.5 \mathrm{mM}$ p-nitrophenylphosphate, $14.5 \mathrm{mM} \mathrm{MgCl} 2,1 \mathrm{mM}$ dithiothreitol, 14.5 mM EGTA, $0.12 \mathrm{mM}$ EDTA, $75 \mathrm{mM}$ genistein (a tyrosine kinase inhibitor), $10 \mu \mathrm{M}$ ML-9 (a myosin light-chain kinase inhibitor), $1 \mathrm{mg} / \mathrm{ml}$ kemptide, $1 \mu \mathrm{g} / \mathrm{ml}$ each of leupeptin, aprotinin, pepstatin, chymostatin, and trypsin-chymotrypsin inhibitor) was added to the tube and the PKA reaction was started by adding $25 \mu \mathrm{l} 20 \mu \mathrm{Ci} / \mathrm{ml}\left[\gamma^{3}{ }^{32} \mathrm{P}\right]$ ATP (Beijing FuRui Biotechnology, Beijing, China) and then incubated for $7 \mathrm{~min}$ at $30^{\circ} \mathrm{C}$. Thereafter, $25 \mu \mathrm{l}$ reaction buffer were extracted and spotted on Whatman p81 paper and the reaction was stopped by $5 \%$ phosphorous acid. After thorough washing, the radioactivity on the paper was counted using a BECKMAN scintillation counter.

To confirm the phosphorylation state of kemptide, a parallel experiment was performed by incubating $1.5 \mu \mathrm{g}$ protein lysate with $50 \mu \mathrm{l}$ reaction buffer described earlier containing $50 \mu \mathrm{Ci} / \mathrm{ml}\left[\gamma^{-32} \mathrm{P}\right]$ ATP at $37^{\circ} \mathrm{C}$ for $30 \mathrm{~min}$. Then equal amount of $2 \times$ SDS sample buffer was added to stop the reaction before resolving the sample by SDS-PAGE and the phosphorylation state of kemptide was detected by autoradiography.

\section{Statistical analysis}

GB-STAT statistical analysis software (version 7.0; Dynamic Microsystems) was used to analyze data from the TER experiment, immunoblot, and Co-IP analysis. All data presented here are results from at least three independent experiments. Statistical significance was determined with one-way ANOVA coupled with two-tailed Dunnett's test. Values represent mean \pm s.D.

\section{Results}

The steady-state level of Rab13 in Sertoli cell BTB in vitro and its interaction with catalytic subunit of PKA

Using the in vitro system of Sertoli cell culturing (Mruk \& Cheng 2011), we found that Rab13 was expressed both in the rat testis and in the Sertoli cells cultured in vitro using an antibody specific to RAB13 (Fig. 1A). However, the

A
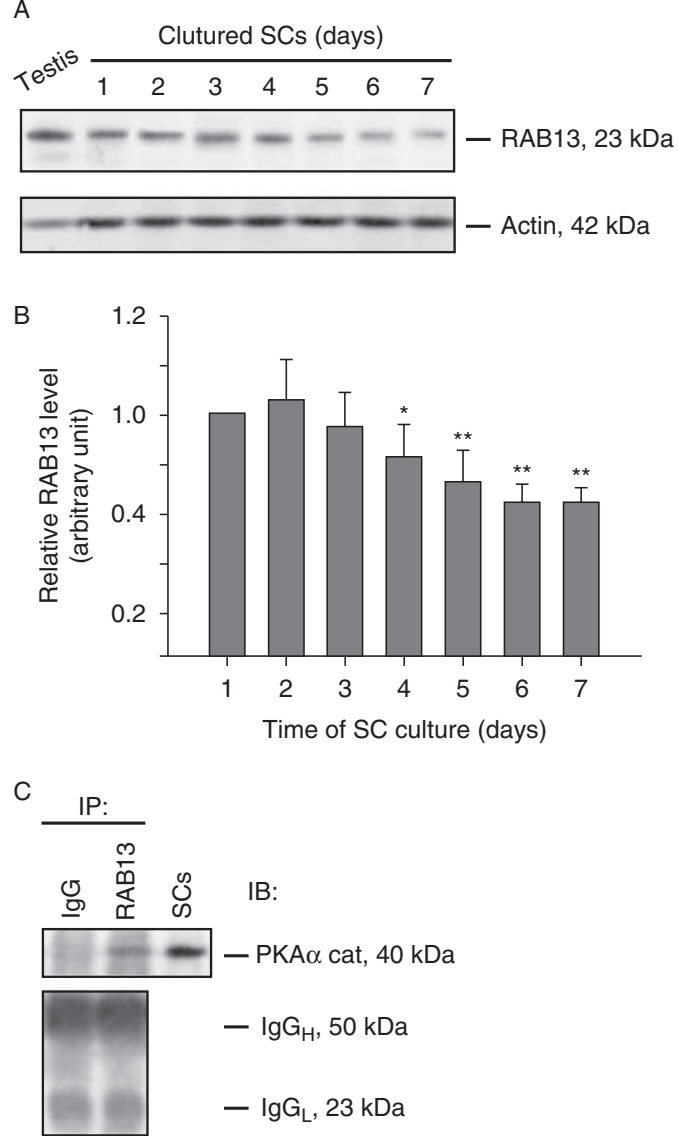

Figure 1

The expression of Rab13 in the rat testis and in Sertoli cell BTB in vitro and its interaction with the catalytic subunit of PKA. (A) Immunoblot analysis of RAB13 in lysate of rat testis ( $80 \mu \mathrm{g}$ protein) or Sertoli cells (SCs) ( $30 \mu \mathrm{g}$ protein) cultured in vitro with a functional TJ barrier established by approximately days 2-3 after isolation. Actin served as a loading control. (B) Histogram corresponds to the result of (A) describing the relative RAB13 level in SCs from days 1 to 7 after each data point was normalized against actin. RAB13 level at day 1 was arbitrarily set at 1 against which statistical comparison was performed. Each bar is a mean \pm s.D. of $n=3$ batches of Sertoli cells. ${ }^{*} P<0.05$ and $* * P<0.01$. (C) Structural interaction between RAB13 and the catalytic subunit of PKA was examined by Co-IP analysis using $500 \mu \mathrm{g}$ protein lysate of SCs cultured for 4 days with an established TJ permeability barrier. SCs lysate ( $30 \mu \mathrm{g}$ protein) alone without Co-IP and with Co-IP using normal rabbit IgG to substitute for the precipitating antibody respectively served as the corresponding positive and negative controls. The blot of $\lg _{H}$ and $I g G_{L}$ chains in the bottom panel illustrated equal IgG/IP-antibody loading in this Co-IP experiment. These findings are representative data from three independent experiments.

Published by Bioscientifica Ltd. 
protein level of Rab13 was detected to decrease during the assembly of the TJ permeability barrier from days 1 to 7 after isolation (Fig. 1A and B). Furthermore, RAB13 was also found to structurally interact with the catalytic subunit of PKA by Co-IP (Fig. 1C), which implied the possible participation of RAB13 in Sertoli cell TJ permeability barrier assembly by regulating the activity of PKA.

\section{The protein level of Rab13 in the Sertoli cells decreases with increasing PKA activity under the treatment of testosterone}

Testosterone was known to promote Sertoli cell BTB integrity by mediating recycling of integral membrane proteins and strengthening the cortical actin filament (F-actin) at the cell-cell interface, resulting in a surge in TJ barrier function (Meng et al. 2005, Yan et al. 2008, Lie et al. 2010a, Su et al. 2012a). Therefore, we herein used the testosterone-treated Sertoli cells as a model of enhanced TJ barrier assembly to explore whether an increased Sertoli cell $\mathrm{TJ}$ assembly is accompanied with changes in protein level of Rab13. Sertoli cells cultured in vitro with an established permeability barrier were treated with either testosterone or vehicle solution from day 4 after isolation and terminated at specified time points. While the protein level of Rab13 decreased steadily during the 48-h experimental period in the vehicle control group, its level in the testosterone-treated group displayed a sharper descending trend, significantly lower vs the corresponding vehicle control from $12 \mathrm{~h}$ after treatment (Fig. 2A and B).

In order to understand whether testosterone can affect PKA activity as the catalytic subunit of PKA was found to directly interact with RAB13, an in vitro phosphorylation system was used and the PKA activity was reflected by the $\left[{ }^{32} \mathrm{P}\right]$ incorporation level of kemptide, a known substrate of PKA, and measured by a radioactivity scintillation counter. Opposite from Rab13 expression, PKA activity in Sertoli cell lysate exhibited an increasing trend after testosterone treatment with significant difference from the control group at time points after $12 \mathrm{~h}$ (Fig. 2C). This result was further supported by a parallel autoradiography experiment with corresponding samples described earlier (Fig. 2D). These results together suggest that RAB13 may participate in the Sertoli cell BTB assembly via affecting PKA activity.

\section{Inhibition of PKA activity antagonizes the enhancing effect of testosterone on Sertoli cell TJ barrier function}

To confirm the role of PKA in testosterone-induced Sertoli cell BTB enhancing, Sertoli cells cultured in vitro were

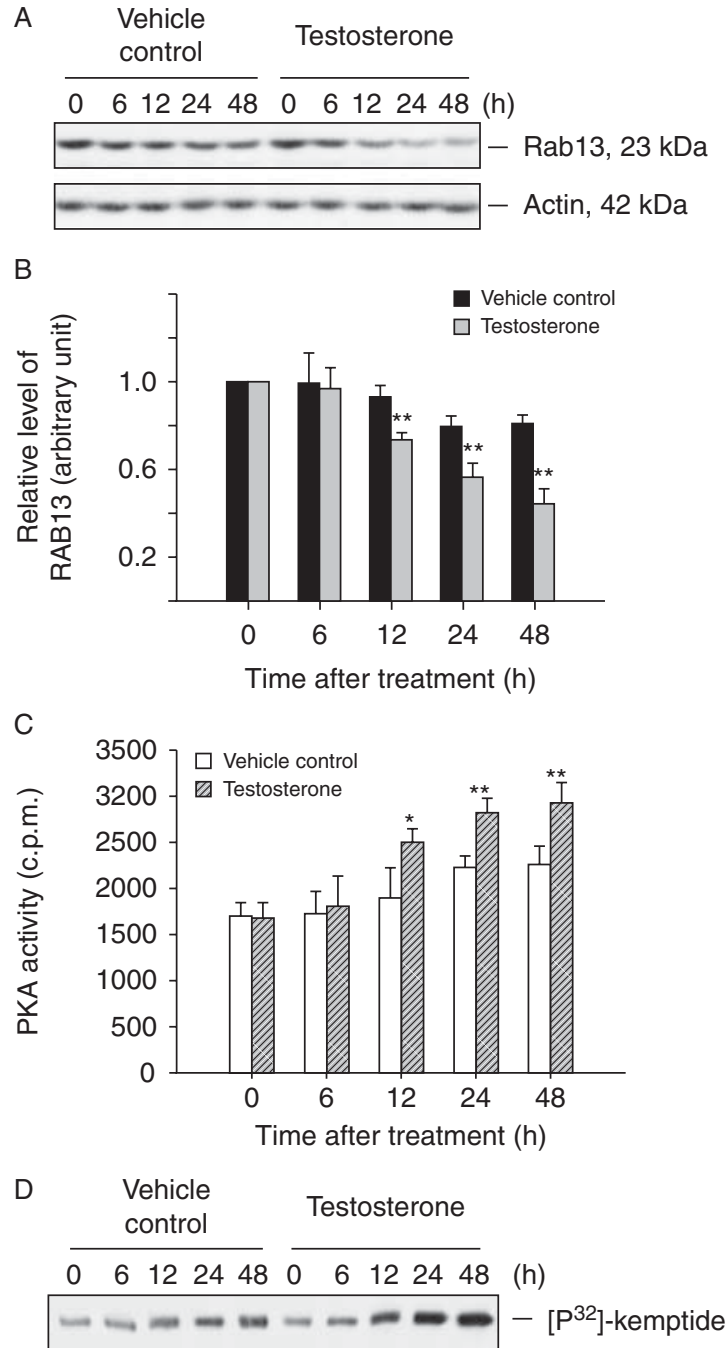

\section{Figure 2}

Effects of testosterone on the protein level of Rab13 and PKA activity in Sertoli cells (SCs) cultured in vitro. (A) Immunoblot analysis of Rab13 protein level using lysates of $\mathrm{SC}(30 \mu \mathrm{g}$ protein) treated with testosterone $(0.2 \mu \mathrm{M})$ from day 4 after isolation for the specified time,

with actin serving as a loading control. The relative RAB13 level decreased after 12-h treatment of testosterone compared with the vehicle control. (B) Histogram summarizing the results shown in (A) after normalizing each data point against actin. RAB13 level at time 0 was arbitrarily set at 1 . Protein level changes were compared between treatment and the corresponding vehicle control at the same time point. Each bar is a mean \pm S.D. of $n=3$ independent experiments. $* * P<0.01$. (C and D) PKA activity analysis using SC lysates after testosterone treatment. For each time point, SCs were lysed and PKA activity was examined by scintillation counting (C) using $0.5 \mu \mathrm{g}$ protein per time point and autoradiography (D)

using $1.5 \mu \mathrm{g}$ protein per time point, with kemptide serving as the PKA substrate. PKA activity changes were compared between treatment and the corresponding vehicle control at the same time point in (C). Each bar is a mean \pm s.D. of $n=3$ independent experiments (C). ${ }^{*} P<0.05$ and $* * P<0.01$. The autoradiograph shown in (D) was representative data from three independent experiments. 
treated with H89, a known inhibitor of PKA (Lochner \& Moolman 2006, Murray 2008), in combination with testosterone from day 4 after isolation. Indeed, testosterone alone was shown to tighten the TJ barrier by causing a significant increase in $\mathrm{TJ}$ integrity compared with the vehicle control as presented by the TER assay (Fig. 3A). Interestingly, the addition of the PKA inhibitor H89 then exhibited a statistically significant inhibition on the effect of testosterone by decreasing TJ integrity, though not to the level as low as the vehicle control (Fig. 3A).

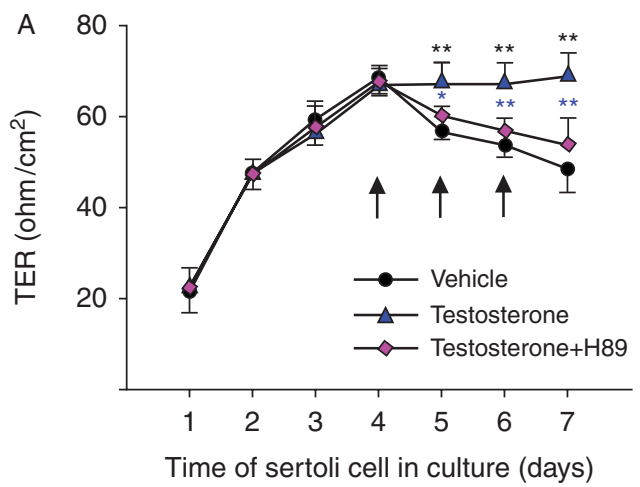

B
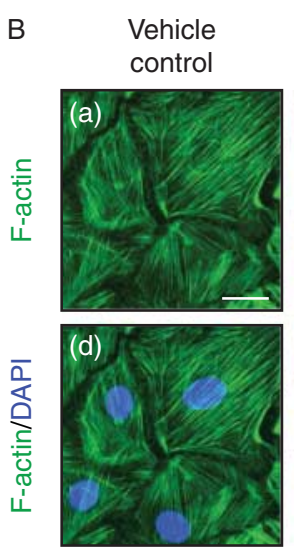

Testosterone
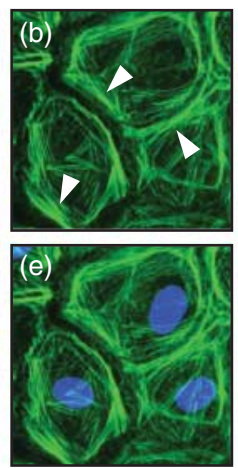

Testosterone+ H89

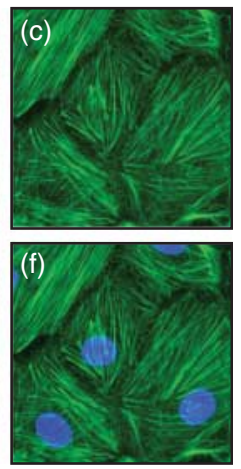

Figure 3

Inhibition of PKA activity by $\mathrm{H} 89$ perturbs the effect of testosterone on Sertoli cell TJ integrity via changes in F-actin conformation. (A) Sertoli cells were cultured at a density of $1.0 \times 10^{6} / \mathrm{cm}^{2}$, and the establishment of a TJ permeability barrier was assessed by TER measurement across the cell epithelium. The TJ barrier was established by day 3 with a stable TER. Cells were then treated with vehicle, testosterone $(0.2 \mu \mathrm{M})$, or a mixture of testosterone and $\mathrm{H} 89$ (testosterone $(0.2 \mu \mathrm{M})+\mathrm{H} 89(30 \mu \mathrm{M}))$ from day 4 to 6 (see black arrows). Each data point is the mean \pm s.D. of $n=3$ replicates. The significant difference was analyzed between testosterone-treated and vehicle control groups (see black stars), or between testosterone- and testosterone $+\mathrm{H} 89$-treated groups (see blue stars). ${ }^{*} P<0.05$ and $* * P<0.01$. (B) F-actin (green) was stained by acti-stain 488 phalloidin (cytoskeleton) in testosterone- or testosterone + H89-treated Sertoli cells $\left(0.05 \times 10^{6} / \mathrm{cm}^{2}\right)$ vs vehicle control. Cell nuclei were visualized with DAPI (blue). Testosterone treatment led to a more intense localization of F-actin at the cell cortex (see arrowheads), whereas testosterone $+\mathrm{H} 89$ treatment kept the F-actin organization similar as in the vehicle control. Scale bar in (B, a), $25 \mu \mathrm{m}$ for all micrograghs in (B).
This finding was further supported by an experiment to visualize actin filaments in the Sertoli cells. It was observed that treatment of testosterone alone led to a more extensive alignment of F-actin at the cell junction sites while the addition of $\mathrm{H} 89$ attenuated this effect and weakened F-actin staining at these positions (Fig. 3B). These results implicated that PKA activity inhibition can reverse the enhancing effect of testosterone on Sertoli cell TJ barrier assembly, at least in part, by maintaining the normal distribution and organization of F-actin, especially at the cell-cell interface.

\section{Knockdown of Rab13 by RNAi in Sertoli cells leads to an increase in PKA activity}

To discriminate whether the change of PKA activity in testosterone-treated Sertoli cells is a result of a decrease in Rab13 expression, Rab13 was knocked down by transfecting Sertoli cells with specific Rab13 siRNA duplexes vs scrambled siRNA control as stated in the Materials and methods section. The immunoblot analysis showed that when Rab13 was silenced by $\sim 70 \%$ compared with the scrambled control, no off-target effect was detected when TJ-associated proteins, namely occludin, JAM-A, and ZO-1, and PKA catalytic subunit $\alpha$ were monitored (Fig. 4A and B). However, the knockdown of Rab13 by $70 \%$ was revealed to lead to an increase in PKA activity vs the control group in the Sertoli cell lysates by $\left[{ }^{32} \mathrm{P}\right]$ incorporation tests (Fig. 4C and D). This finding further prompted the notion that RAB13 may participate in Sertoli cell TJ barrier assembly by regulating the activity of PKA.

\section{RAB13 participates in Sertoli cell TJ dynamics by regulating F-actin organization, junction protein recruitment, and protein-protein interaction through PKA}

As the steady-state level of RAB13 decreased during the increment of Sertoli cell TJ barrier caused by testosterone, RAB13 was also knocked down in a TJ integrity assay to reveal its relationship with Sertoli cell BTB assembly in vitro. After transfection with the siRNA duplexes targeting Rab13 in Sertoli cells cultured on Matrigel-coated bicameral unit for $24 \mathrm{~h}$ from day 3 after isolation, the Sertoli cell TJ permeability barrier was shown to increase significantly compared with the non-targeting control (Fig. 5A). Notably, the addition of the PKA inhibitor H89 was found to antagonize the effect of Rab13 silencing by reducing the TJ barrier function vs the group only treated with Rab13 siRNA.

To explore the mechanism by which PKA activity affects the phenotype of Sertoli cells caused by Rab13

Published by Bioscientifica Ltd 
silencing, F-actin, the cytoskeleton that participates in the formation of Sertoli cell BTB by lying perpendicular to the cell plasma and sandwiched between the cisternae of endoplasmic reticulum and the apposing Sertoli cell plasma membranes (Vogl et al. 2000, Cheng \& Mruk 2010, 2012), and occludin, the TJ constitution protein (Nelson \& Yeaman 2001, Mruk et al. 2008), were visualized under fluorescence microscopy. The results showed that F-actin staining after Rab13 silencing resembled that after testosterone treatment, i.e. with a remarkably concentrated signal at the cell cortex near the plasma membrane (Fig. 5B b and e vs a and d), while the inhibition of PKA by
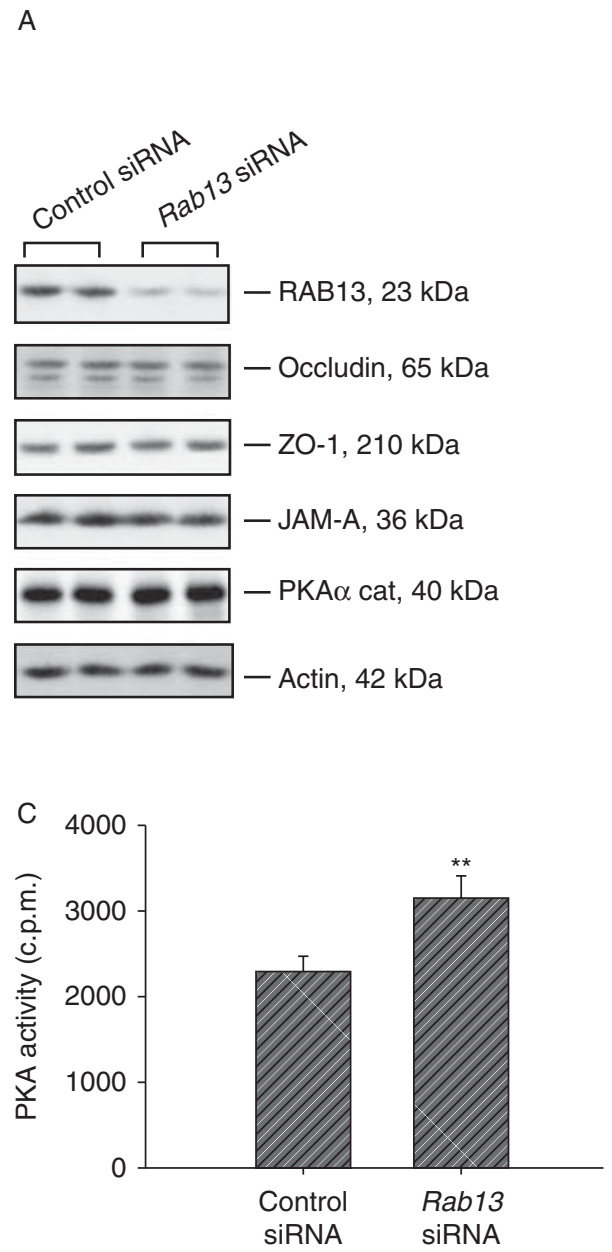

H89 was found to resist the effect of Rab13 knockdown on F-actin reorganization and present an even F-actin distribution (Fig. 5B $\mathrm{c}$ and $\mathrm{f}$ vs $\mathrm{b}$ and e). A very similar variation in occludin localization was visualized by immunofluorescence: an intensified signal at the cellcell interface after Rab13 silencing (Fig. 5C b and e vs a and d) but this remained unchanged when H89 was applied in addition to Rab13 siRNA duplexes (Fig. 5C c and $f$ vs $b$ and e), which may lead to the changes in TER together with F-actin reorganization.

Because Rab13 knockdown by RNAi was found to increase the Sertoli cell TJ barrier in vitro without affecting
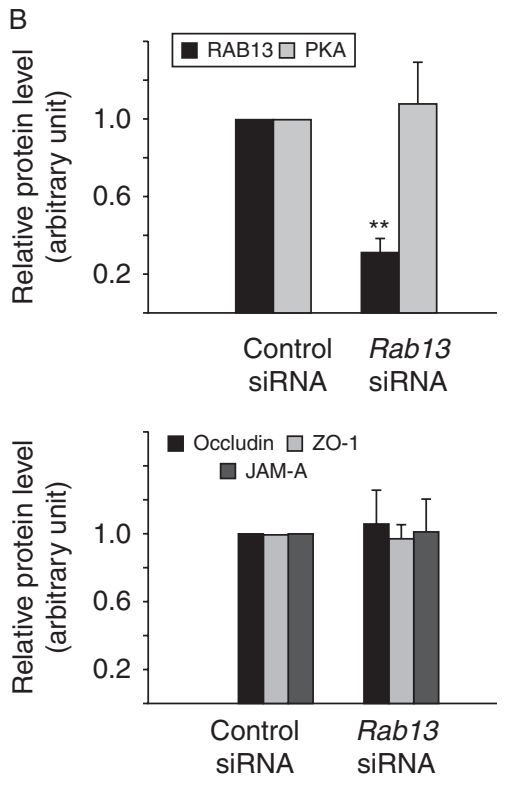

D

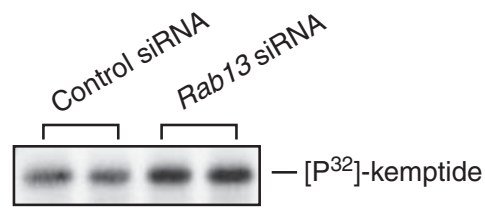

\section{Figure 4}

Knockdown of Rab13 by RNAi in Sertoli cells affects the activity of PKA. (A) Sertoli cells $\left(0.5 \times 10^{6} / \mathrm{cm}^{2}\right)$ were cultured alone for 4 days before being transfected with specific Rab13 siRNA vs scrambled control siRNA duplexes for $24 \mathrm{~h}$. Cultures were terminated $72 \mathrm{~h}$ later to obtain lysates for immunoblot analysis, which detected no off-target effect on several BTB proteins (i.e. occludin, ZO-1, and JAM-A) and the catalytic subunit $\alpha$ of PKA (PKA $\alpha$ cat) when Rab13 was knocked down significantly. (B) Histograms based on immunoblot results shown in $(A)$ after normalizing the data Printed in Great Britain against actin. The upper panel illustrates that the efficacy of Rab13 RNAi is $\sim 70 \%$. Protein levels in the control were arbitrarily set at 1 . Each bar is mean \pm s.D. of $n=3$ independent experiments. ${ }^{*} P<0.01$. (C and D) PKA activity analysis using Sertoli cell lysates after Rab13 knockdown by scintillation counting (C) and autoradiography (D). The incorporation of $\left[\mathrm{P}^{32}\right]$ in kemptide was increased by about $30 \%$ in the Rab13 silencing group vs the scrambled control group, representing an increment in PKA activity. Bar is mean \pm s.D. of $n=3$ independent experiments. $* * P<0.01$.

Published by Bioscientifica Ltd 


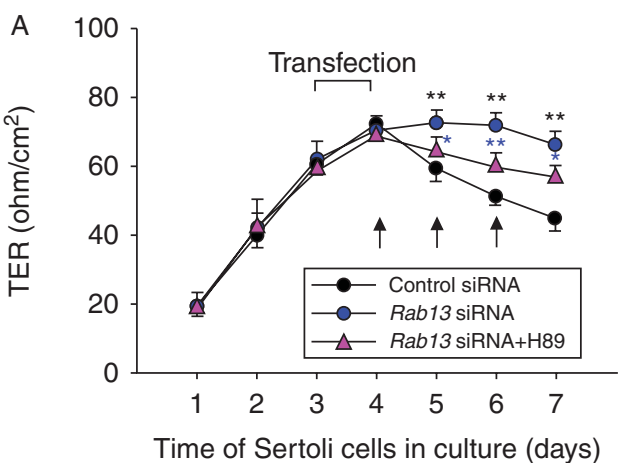

B

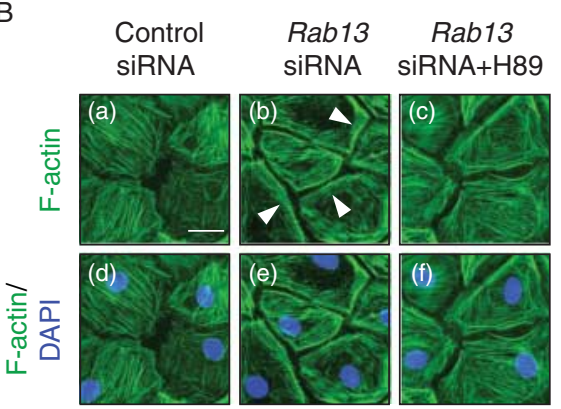

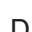

IP:

ZO-1

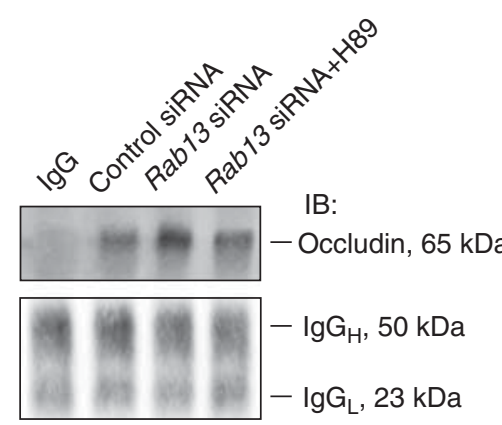

C

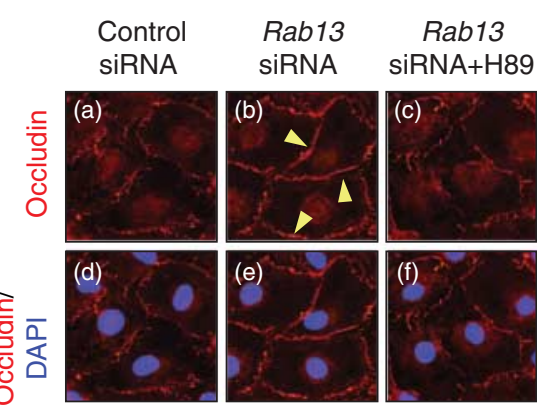

E

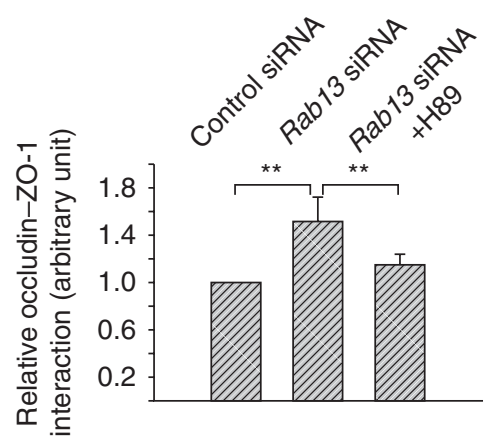

\section{Figure 5}

RAB13 regulates Sertoli cell BTB integrity in vitro by regulating F-actin organization, junction protein recruitment, and protein-protein interaction through PKA. (A) Sertoli cells cultured on Matrigel-coated bicameral units were assessed by TER measurement across the cell epithelium daily after isolation. On day 3, cells were treated with specific Rab13 siRNA vs scrambled control siRNA duplexes for $24 \mathrm{~h}$. In some Rab13 siRNA treated groups, $\mathrm{H} 89(30 \mu \mathrm{M})$ was added to the culture medium daily after transfection (see black arrows). Each data point is the mean +s.D. of $n=3$ replicates. The significant difference was analyzed between Rab13 siRNA and control groups (see black stars) or between Rab13 siRNA and Rab13 siRNA + H89 groups (see blue stars). The graph shown here was representative data from three independent experiments. ${ }^{*} P<0.05$ and $* * P<0.01$. (B and C) F-actin (green, B) and occludin (red, C) were stained in Rab13 siRNA- or Rab13 siRNA + H89-treated Sertoli cells $\left(0.05 \times 10^{6} / \mathrm{cm}^{2}\right)$ vs scrambled siRNA control. Cell nuclei were visualized with DAPI (blue). Rab13 knockdown led to a more concentrated distribution of F-actin the near cell membrane (see white arrowheads in (B)) and a more intense signal of occludin at the cell-cell interface (see yellow arrowheads in (C)), while the addition of $\mathrm{H} 89$ treatment kept the distribution of F-actin or occludin similar with that of the control. Scale bar in (B, a), $25 \mu \mathrm{m}$ for all micrograghs in (B) and (C). (D) Co-IP was performed to assess changes in protein-protein interactions between ZO-1 and occludin using $500 \mu \mathrm{g}$ protein lysate from Sertoli cells $\left(0.5 \times 10^{6} / \mathrm{cm}^{2}\right)$ following RNA interference. Co-IP using normal rabbit IgG to substitute for the precipitating antibody served as the negative control. The blot of $\operatorname{lgG}_{H}$ and $\operatorname{lgG}_{\mathrm{L}}$ chains in the bottom panel illustrated equal Ig G/IP-antibody loading in this Co-IP experiment. This finding is representative data from three independent experiments. (E) Histogram summarizes the result shown in (D) in which the relative association of occludin and ZO-1 in control group was arbitrarily set at 1 . Each bar represents a mean \pm s.D. of $n=3$ independent experiments. $* * P<0.01$ 
the steady-state levels of junction proteins but upregulating the recruitment of occludin to cell-cell interface, we next performed Co-IP to examine whether there was any alteration of protein-protein interactions in adhesion complexes at the Sertoli cell BTB. As anticipated, there was an increased interaction between TJ protein occludin and ZO- 1 after Rab13 silencing by $\sim 40 \%$ compared with the scrambled siRNA control group, which was significantly weakened in the group treated with both Rab13 siRNA duplexes and H89 (Fig. 5D and E).

\section{Discussion}

To date, more than 60 Rab GTPases have been discovered and defined as small GTP-binding proteins of 20-30 kDa that belong to the Ras GTPase superfamily, the key regulators of protein traffic in compartmentalized eukaryotic cells (Olkkonen \& Stenmark 1997, Schimmoller et al. 1998, Deneka et al. 2003, Hutagalung \& Novick 2011). Rab GTPases exert their roles in multiple cellular events such as transport, recycling, endocytosis, exocytosis, and cytoskeletal organization, primarily by converting between the active GTP-bound and the inactive GDPbound forms, which is regulated by GDP/GTP exchange factor, GTPase activating protein, and GDP dissociation inhibitor (Hall 1994, Takai et al. 1995, 1996, Mruk et al. 2005). In epithelial cells, RAB3B, RAB8, and RAB13 have been found to exist at the cell-cell contacts and have cross talk with tight or adherens junctions (Huber et al. 1993, Weber et al. 1994, Zahraoui et al. 1994). For instance, many reports have revealed the mediation of E-cadherin endocytosis by Rab proteins during cell junction disassembly (Maxfield \& McGraw 2004, Lock \& Stow 2005, Palacios et al. 2005).

In the testis, several Rab proteins have been demonstrated to exist and exert their roles during spermatogenesis within the seminiferous epithelium. For example, RAB8B was shown to associate with the cytoskeletal networks and participate in Sertoli-germ cell junction dynamics in the testis (Lau \& Mruk 2003). The association between RAB4A and adherens junction signaling protein $\alpha$ - and $\beta$-catenin was also reported to increase during the junction restructuring accompanied with the loss of spermatocytes and spermatids from the seminiferous epithelium under the treatment of adjudin, a male contraceptive known to induce germ cell loss from the epithelium (Cheng et al. 2005, Mruk et al. 2007). Although RAB13, another member of Rab GTPase family, has been found to participate in the apical ES dynamics between Sertoli and elongating/elongated spermatids
(Mruk \& Lau 2009), it seems no investigation was performed to clarify its role in $\mathrm{TJ}$ assembly/restructuring between Sertoli cells, which is considered as a crucial 'switch' of the BTB for the transit of preleptotene spermatocytes at stage VIII of the epithelial cycle.

In this report, we demonstrated that RAB13 is the likely regulator of TJ dynamics at the BTB using primarily cultured Sertoli cell epithelium in vitro, which has been confirmed to mimic the BTB in vivo and is widely used by investigators to study the biology and regulation of BTB dynamics (Byers et al. 1986, Janecki et al. 1991b, Grima et al. 1992, Kato et al. 2006, Chen et al. 2012, Robillard et al. 2012). First, using an antibody specific to Rab13, Rab13 was shown to exist in both testis and Sertoli cell lysates. Interestingly, its protein level decreased during the assembly of the Sertoli cell TJ-permeability barrier in vitro after isolation, implying that its expression is relevant to BTB dynamics. This postulate is further supported by findings using an in vitro model in which the Sertoli cell BTB is promoted under the treatment of testosterone, which has been verified to increase endocytosis of integral membrane proteins, such as occludin and N-cadherin, at the BTB and induce recycling of endocytosed proteins back to the Sertoli cell surface (Cheng \& Mruk 2010, 2012). After the treatment of testosterone for $12 \mathrm{~h}$, the steady-state level of RAB13 was found to decrease significantly compared with the control group, prompting a negative correlation between RAB13 and Sertoli cell TJ assembly. Indeed, a knockdown of Rab13 by RNAi was shown to associate with an increment of the Sertoli cell TJ-permeability barrier, probably due to the strengthened localization of F-actin and occludin at the cell-cell interface visualized under fluorescence microscopy. More importantly, an increased protein-protein interaction was also detected between occludin and ZO-1 after Rab13 silencing, though the total level of these junction proteins remained unchanged. These data seem to support the notion that RAB13 participates in Sertoli cell BTB dynamics by regulating junction protein endocytosis and recycling, coinciding with a recent study in epithelial MTD-1A cells, which revealed that a dominant active mutant of Rab13 inhibited continuous endocytic recycling of occludin to the cell surface (Morimoto et al. 2005).

Studies in other epithelia including blood-tissue barriers have indicated that the phosphorylation status of integral membrane proteins (e.g. occludin, claudins, and $\mathrm{N}$-cadherin) and peripheral adaptors (e.g. $\beta$-catenin) at cell-cell junctions play a key role in determining adhesive function at the cell-cell interface (Gumbiner 2000, Cheng \& Mruk 2002, Dorfel et al. 2009, Findley \&

Published by Bioscientifica Ltd. 
Koval 2009, Raleigh et al. 2011). Actually, many cellular signaling proteins such as PKA and various PKC isotypes are involved in epithelial cell TJ dynamics (Balda et al. 1993, Denisenko et al. 1994). For example, it was found in T84 intestinal epithelial cells that an elevation of intracellular cAMP level enhanced the barrier function while an inhibition of PKA diminished barrier recovery (Lawrence et al. 2002). In epithelial MDCK cells, PKA signaling was also demonstrated to play a significant role in TJ assembly by recruiting claudin 1 and $\mathrm{ZO}-1$ to the $\mathrm{TJ}$ and regulating the phosphorylation and distribution of the actin-binding protein VASP (Kohler et al. 2004). In this study, we detected a structural interaction between RAB13 and the catalytic subunit $\alpha$ of PKA. Furthermore, the decline of RAB13 in Sertoli cell epithelium induced by testosterone was found to be accompanied by an increased PKA activity. In order to discriminate whether this change in PKA activity was caused by RAB13 declination, we performed RNA interference to knockdown Rab13 in cultured Sertoli cells and found an increment of PKA activity following $~ 70 \%$ knockdown of Rab13 expression. Importantly, the enhancing effects of both testosterone and Rab13 silencing on the Sertoli cell TJ barrier can be antagonized by the PKA activity inhibitor H89, which

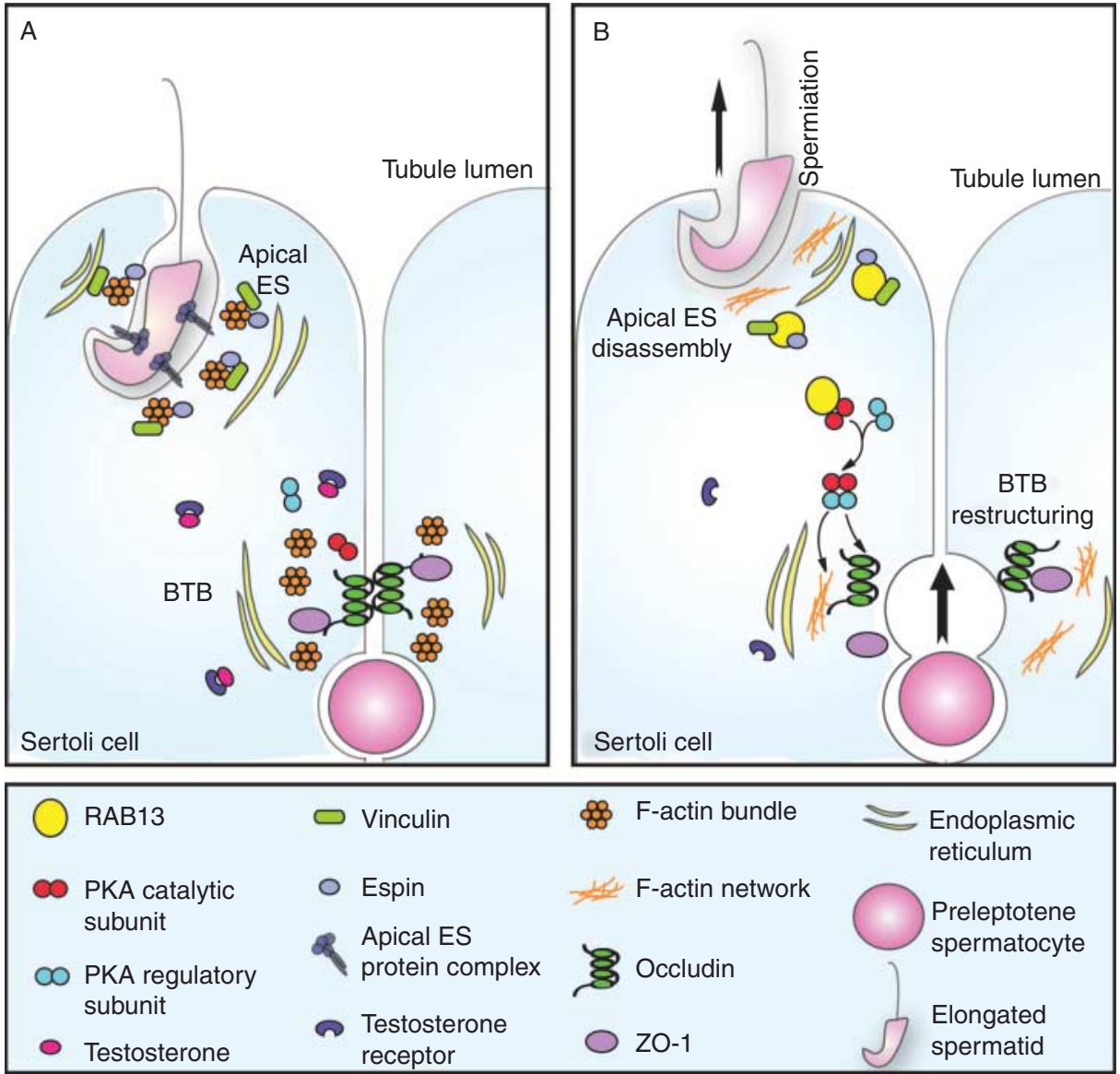

\section{Figure 6}

A schematic drawing illustrating the possible role of RAB13 in BTB restructuring and apical ES disassembly. (A) Seminiferous epithelium with intact cell junctions at the apical ES and the BTB, according to most of the seminiferous epithelial cycle of adult rat testis except stages VIII-IX. Actin filaments at these two sites are tightly bundled to provide powerful support for the junction complexes. The status of the junction integrity at the apical ES and the BTB is maintained, at least in part, by the relative contribution of testosterone, which is known not only to facilitate junction protein recycling for junction assembly but also responsible for F-actin organization underneath the Sertoli cell cortex. (B) Restructuring http://jme.endocrinology-journals.org DOI: 10.1530/JME-13-0011
C 2013 Society for Endocrinology Printed in Great Britain seminiferous epithelium with simultaneous happening of apical ES disassembly and BTB restructuring, according to stages VII-IX of the seminiferous epithelial cycle. The lower level of testosterone at these stages increases the Rab13 expression, which might interact directly with espin or viculin (Mruk \& Lau 2009), two actin-bundling proteins, inducing disassembly of F-actin bundles and then disassembly of the apical ES. On the other hand, the enhancing level of RAB13 at the BTB could lead to an inactivation of PKA in Sertoli cells, which in turn results in a trafficking of TJ protein (i.e. occludin) to cell cytosol and the breakdown of the BTB, facilitating the process of spermatogenesis.

Published by Bioscientifica Ltd. 
emphasized the possibility that PKA might work as a downstream effecter of RAB13 in regulating BTB dynamics. This postulation was inconsistent with a previous study investigating the role of RAB13 in $\mathrm{TJ}$ dynamics in MDCK cells (Kohler et al. 2004).

In summary, we here suggest that RAB13 is a regulator of Sertoli cell BTB dynamics via its effects on PKA activity. Thus, besides participating in apical ES dynamics at the Sertoli-germ cell interface (Mruk \& Lau 2009), RAB13 may also exert its role in integral membrane protein trafficking to facilitate BTB dynamics between adjacent Sertoli cells during the seminiferous epithelial cycle (Fig. 6). This process must involve reorganizations of actin filament distribution at the Sertoli cell cortex. In this context, it will be of interest in future studies to determine the actinregulating molecules downstream of the RAB13-PKA pathway in rearranging F-actin underneath the Sertoli cell membrane, which is considered as a particular feature that characterizes BTB dynamics (Cheng \& Mruk 2002, 2010).

\section{Declaration of interest}

The authors declare that there is no conflict of interest that could be perceived as prejudicing the impartiality of the research reported.

\section{Funding}

This work was supported by grants from the National Natural Science Foundation of China (81100462 to W S) and the Specialized Research Fund for the Doctoral Program of Higher Education of China (20102104120027 to $\mathrm{W} \mathrm{S}$ ).

\section{Acknowledgements}

The authors are grateful to Dr C Yan Cheng at the Mary M Wohlford Laboratory for Male Contraceptive Research, Center for Biomedical Research, Population Council, New York, and members of the same laboratory, Drs Elissa W P Wong, Dolores D Mruk, and Pearl P Y Lie, who have provided much guidance and help in the primary culture of the rat Sertoli cells during the past 2 years.

\section{References}

Balda MS, Gonzalez-Mariscal L, Matter K, Cereijido M \& Anderson JM 1993 Assembly of the tight junction: the role of diacylglycerol. Journal of Cell Biology 123 293-302. (doi:10.1083/jcb.123.2.293)

Benais-Pont G, Punn A, Flores-Maldonado C, Eckert J, Raposo G, Fleming TP, Cereijido M, Balda MS \& Matter K 2003 Identification of a tight junction-associated guanine nucleotide exchange factor that activates Rho and regulates paracellular permeability. Journal of Cell Biology 160 729-740. (doi:10.1083/jcb.200211047)

Byers SW, Hadley MA, Djakiew D \& Dym M 1986 Growth and characterization of polarized monolayers of epididymal epithelial cells and Sertoli cells in dual environment culture chambers. Journal of Andrology 7 59-68.
Chavrier P \& Goud B 1999 The role of ARF and Rab GTPases in membrane transport. Current Opinion in Cell Biology 11 466-475. (doi:10.1016/ S0955-0674(99)80067-2)

Chen J, Fok KL, Chen H, Zhang XH, Xu WM \& Chan HC 2012 Cryptorchidism-induced CFTR down-regulation results in disruption of testicular tight junctions through up-regulation of NF- $\kappa \mathrm{B} /$ COX-2/PGE2. Human Reproduction 27 2585-2597. (doi:10.1093/ humrep/des254)

Cheng CY \& Mruk DD 2002 Cell junction dynamics in the testis: Sertoli-germ cell interactions and male contraceptive development. Physiological Reviews 82 825-874. (doi:10.1152/physrev.00009.2002)

Cheng CY \& Mruk DD 2010 A local autocrine axis in the testes that regulates spermatogenesis. Nature Reviews. Endocrinology 6 380-395. (doi:10.1038/nrendo.2010.71)

Cheng CY \& Mruk DD 2012 The blood-testis barrier and its implications for male contraception. Pharmacological Reviews 64 16-64. (doi:10.1124/pr. 110.002790)

Cheng CY, Mruk D, Silvestrini B, Bonanomi M, Wong CH, Siu MK, Lee NP, Lui WY \& Mo MY 2005 AF-2364 [1-(2,4-dichlorobenzyl)-1H-indazole3-carbohydrazide] is a potential male contraceptive: a review of recent data. Contraception 72 251-261. (doi:10.1016/j.contraception.2005. 03.008)

Cheng CY, Lie PP, Mok KW, Cheng YH, Wong EW, Mannu J, Mathur PP, Yan HH \& Mruk DD 2011a Interactions of laminin $\beta 3$ fragment with $\beta 1$-integrin receptor: a revisit of the apical ectoplasmic specializationblood-testis-barrier-hemidesmosome functional axis in the testis. Spermatogenesis 1 174-185. (doi:10.4161/spmg.1.3.17076)

Cheng CY, Wong EW, Lie PP, Li MW, Mruk DD, Yan HH, Mok KW, Mannu J, Mathur PP, Lui WY et al. $2011 b$ Regulation of blood-testis barrier dynamics by desmosome, gap junction, hemidesmosome and polarity proteins: an unexpected turn of events. Spermatogenesis 1 105-115. (doi:10.4161/spmg.1.2.15745)

Deneka M, Neeft M \& van der Sluijs P 2003 Regulation of membrane transport by rab GTPases. Critical Reviews in Biochemistry and Molecular Biology 38 121-142. (doi:10.1080/713609214)

Denisenko N, Burighel P \& Citi S 1994 Different effects of protein kinase inhibitors on the localization of junctional proteins at cell-cell contact sites. Journal of Cell Science 107 (Pt 4) 969-981.

Dorfel MJ, Westphal JK \& Huber O 2009 Differential phosphorylation of occludin and tricellulin by CK2 and CK1. Annals of the New York Academy of Sciences 1165 69-73. (doi:10.1111/j.1749-6632.2009. 04043.x)

Echard A, Jollivet F, Martinez O, Lacapere JJ, Rousselet A, Janoueix-Lerosey I \& Goud B 1998 Interaction of a Golgi-associated kinesin-like protein with Rab6. Science 279 580-585. (doi:10.1126/science. 279.5350.580)

Findley MK \& Koval M 2009 Regulation and roles for claudin-family tight junction proteins. IUBMB Life 61 431-437. (doi:10.1002/iub.175)

Green KJ \& Simpson CL 2007 Desmosomes: new perspectives on a classic. Journal of Investigative Dermatology 127 2499-2515. (doi:10.1038/sj.jid. 5701015)

Green KJ, Getsios S, Troyanovsky S \& Godsel LM 2010 Intercellular junction assembly, dynamics, and homeostasis. Cold Spring Harbor Perspectives in Biology 2 a000125. (doi:10.1101/cshperspect.a000125)

Grieco D, Avvedimento EV \& Gottesman ME 1994 A role for cAMPdependent protein kinase in early embryonic divisions. PNAS 91 9896-9900. (doi:10.1073/pnas.91.21.9896)

Grima J, Pineau C, Bardin CW \& Cheng CY 1992 Rat Sertoli cell clusterin a2-macroglobulin, and testins: biosynthesis and differential regulation by germ cells. Molecular and Cellular Endocrinology 89 127-140. (doi:10.1016/0303-7207(92)90219-V)

Grima J, Wong CC, Zhu LJ, Zong SD \& Cheng CY 1998 Testin secreted by Sertoli cells is associated with the cell surface, and its expression correlates with the disruption of Sertoli-germ cell junctions but not the inter-Sertoli tight junction. Journal of Biological Chemistry 273 21040-21053. (doi:10.1074/jbc.273.33.21040) 
Gumbiner BM 2000 Regulation of cadherin adhesive activity. Journal of Cell Biology 148 399-404. (doi:10.1083/jcb.148.3.399)

Hall A 1994 Small GTP-binding proteins and the regulation of the actin cytoskeleton. Annual Review of Cell Biology 10 31-54. (doi:10.1146/ annurev.cb.10.110194.000335)

Huber LA, Pimplikar S, Parton RG, Virta H, Zerial M \& Simons K 1993 Rab8, a small GTPase involved in vesicular traffic between the TGN and the basolateral plasma membrane. Journal of Cell Biology 123 35-45. (doi:10.1083/jcb.123.1.35)

Hutagalung AH \& Novick PJ 2011 Role of Rab GTPases in membrane traffic and cell physiology. Physiological Reviews 91 119-149. (doi:10.1152/ physrev.00059.2009)

Janecki A, Jakubowiak A \& Steinberger A 1991a Effects of cyclic AMP and phorbol ester on transepithelial electrical resistance of Sertoli cell monolayers in two-compartment culture. Molecular and Cellular Endocrinology 82 61-69. (doi:10.1016/0303-7207(91)90009-H)

Janecki A, Jakubowiak A \& Steinberger A 1991b Regulation of transepithelial electrical resistance in two-compartment Sertoli cell cultures: in vitro model of the blood-testis barrier. Endocrinology 129 1489-1496. (doi:10.1210/endo-129-3-1489)

Janecki A, Jakubowiak A \& Steinberger A 1992 Effect of cadmium chloride on transepithelial electrical resistance of Sertoli cell monolayers in twocompartment cultures - a new model for toxicological investigations of the "blood-testis" barrier in vitro. Toxicology and Applied Pharmacology 112 51-57. (doi:10.1016/0041-008X(92)90278-Z)

Kato R, Maeda T, Akaike T \& Tamai I 2006 Characterization of novel $\mathrm{Na}+$-dependent nucleobase transport systems at the blood-testis barrier. American Journal of Physiology. Endocrinology and Metabolism 290 E968-E975. (doi:10.1152/ajpendo.00160.2005)

Kohler K, Louvard D \& Zahraoui A 2004 Rab13 regulates PKA signaling during tight junction assembly. Journal of Cell Biology 165 175-180. (doi:10.1083/jcb.200312118)

Lau AS \& Mruk DD 2003 Rab8B GTPase and junction dynamics in the testis. Endocrinology 144 1549-1563. (doi:10.1210/en.2002-220893)

Lawrence DW, Comerford KM \& Colgan SP 2002 Role of VASP in reestablishment of epithelial tight junction assembly after $\mathrm{Ca}^{2+}$ switch. American Journal of Physiology. Cell Physiology 282 C1235-C1245. (doi:10.1152/ajpcell.00288.2001)

Lee NP \& Cheng CY 2003 Regulation of Sertoli cell tight junction dynamics in the rat testis via the nitric oxide synthase/soluble guanylate cyclase $/ 3^{\prime}, 5^{\prime}$-cyclic guanosine monophosphate/protein kinase $\mathrm{G}$ signaling pathway: an in vitro study. Endocrinology 144 3114-3129. (doi:10.1210/en.2002-0167)

Lee NP, Mruk DD, Conway AM \& Cheng CY 2004 Zyxin, axin, and Wiskott-Aldrich syndrome protein are adaptors that link the cadherin/catenin protein complex to the cytoskeleton at adherens junctions in the seminiferous epithelium of the rat testis. Journal of Andrology 25 200-215.

Li JC, Lee TW, Mruk TD \& Cheng CY 2001 Regulation of Sertoli cell myotubularin (rMTM) expression by germ cells in vitro. Journal of Andrology 22 266-277.

Li MW, Xia W, Mruk DD, Wang CQ, Yan HH, Siu MK, Lui WY, Lee WM \& Cheng CY 2006 Tumor necrosis factor $\{\alpha\}$ reversibly disrupts the bloodtestis barrier and impairs Sertoli-germ cell adhesion in the seminiferous epithelium of adult rat testes. Journal of Endocrinology 190 313-329. (doi:10.1677/joe.1.06781)

Li MW, Xiao X, Mruk DD, Lam YL, Lee WM, Lui WY, Bonanomi M, Silvestrini B \& Cheng CY 2011 Actin-binding protein drebrin E is involved in junction dynamics during spermatogenesis. Spermatogenesis 1 123-136. (doi:10.4161/spmg.1.2.16393)

Lie PP, Mruk DD, Lee WM \& Cheng CY 2009 Epidermal growth factor receptor pathway substrate 8 (Eps8) is a novel regulator of cell adhesion and the blood-testis barrier integrity in the seminiferous epithelium. FASEB Journal 23 2555-2567. (doi:10.1096/fj.06-070573)

Lie PP, Chan AY, Mruk DD, Lee WM \& Cheng CY 2010a Restricted Arp3 expression in the testis prevents blood-testis barrier disruption during junction restructuring at spermatogenesis. PNAS 107 11411-11416. (doi:10.1073/pnas.1001823107)

Lie PP, Cheng CY \& Mruk DD 2010b Crosstalk between desmoglein2/desmocollin-2/Src kinase and coxsackie and adenovirus receptor/ ZO-1 protein complexes, regulates blood-testis barrier dynamics. International Journal of Biochemistry \& Cell Biology 42 975-986. (doi:10.1016/j.biocel.2010.02.010)

Lie PP, Mruk DD, Mok KW, Su L, Lee WM \& Cheng CY 2012 Focal adhesion kinase-Tyr407 and -Tyr397 exhibit antagonistic effects on blood-testis barrier dynamics in the rat. PNAS 109 12562-12567. (doi:10.1073/ pnas.1202316109)

Lochner A \& Moolman JA 2006 The many faces of H89: a review. Cardiovascular Drug Reviews 24 261-274. (doi:10.1111/j.1527-3466. 2006.00261.x)

Lock JG \& Stow JL 2005 Rab11 in recycling endosomes regulates the sorting and basolateral transport of E-cadherin. Molecular Biology of the Cell 16 1744-1755. (doi:10.1091/mbc.E04-10-0867)

Lui WY, Lee WM \& Cheng CY 2001 Transforming growth factor- $\beta 3$ perturbs the inter-Sertoli tight junction permeability barrier in vitro possibly mediated via its effects on occludin, zonula occludens-1, and claudin-11. Endocrinology 142 1865-1877. (doi:10.1210/en.142.5.1865)

Madara JL, Barenberg D \& Carlson S 1986 Effects of cytochalasin D on occluding junctions of intestinal absorptive cells: further evidence that the cytoskeleton may influence paracellular permeability and junctional charge selectivity. Journal of Cell Biology 102 2125-2136. (doi:10.1083/jcb.102.6.2125)

Madara JL, Parkos C, Colgan S, Nusrat A, Atisook K \& Kaoutzani P 1992 The movement of solutes and cells across tight junctions. Annals of the New York Academy of Sciences 664 47-60. (doi:10.1111/j.1749-6632. 1992.tb39748.x)

Maxfield FR \& McGraw TE 2004 Endocytic recycling. Nature Reviews. Molecular Cell Biology 5 121-132. (doi:10.1038/nrm1315)

Meng J, Holdcraft RW, Shima JE, Griswold MD \& Braun RE 2005 Androgens regulate the permeability of the blood-testis barrier. PNAS 102 16696-16700. (doi:10.1073/pnas.0506084102)

Morimoto S, Nishimura N, Terai T, Manabe S, Yamamoto Y, Shinahara W, Miyake H, Tashiro S, Shimada M \& Sasaki T 2005 Rab13 mediates the continuous endocytic recycling of occludin to the cell surface. Journal of Biological Chemistry 280 2220-2228. (doi:10.1074/jbc.M406906200)

Mruk DD \& Cheng CY 2011 An in vitro system to study Sertoli cell bloodtestis barrier dynamics. Methods in Molecular Biology 763 237-252. (doi:10.1007/978-1-61779-191-8_16)

Mruk DD \& Lau AS 2009 RAB13 participates in ectoplasmic specialization dynamics in the rat testis. Biology of Reproduction 80 590-601. (doi:10.1095/biolreprod.108.071647)

Mruk DD, Lau AS \& Conway AM 2005 Crosstalk between Rab GTPases and cell junctions. Contraception 72 280-290. (doi:10.1016/j.contraception. 2005.03.013)

Mruk DD, Lau AS, Sarkar O \& Xia W 2007 Rab4A GTPase-catenin interactions are involved in cell junction dynamics in the testis. Journal of Andrology 28 742-754. (doi:10.2164/jandrol.106.002204)

Mruk DD, Silvestrini B \& Cheng CY 2008 Anchoring junctions as drug targets: role in contraceptive development. Pharmacological Reviews 60 146-180. (doi:10.1124/pr.107.07105)

Murray AJ 2008 Pharmacological PKA inhibition: all may not be what it seems. Science Signaling 1 re4. (doi:10.1126/scisignal.122re4)

Nelson WJ \& Yeaman C 2001 Protein trafficking in the exocytic pathway of polarized epithelial cells. Trends in Cell Biology 11 483-486. (doi:10.1016/S0962-8924(01)02145-6)

Nielsen E, Severin F, Backer JM, Hyman AA \& Zerial M 1999 Rab5 regulates motility of early endosomes on microtubules. Nature Cell Biology 1 376-382. (doi:10.1038/14075)

Okanlawon A \& Dym M 1996 Effect of chloroquine on the formation of tight junctions in cultured immature rat Sertoli cells. Journal of Andrology 17 249-255. 
Olkkonen VM \& Stenmark H 1997 Role of Rab GTPases in membrane traffic. International Review of Cytology 176 1-85.

Orth JM 1982 Proliferation of Sertoli cells in fetal and postnatal rats: a quantitative autoradiographic study. Anatomical Record 203 485-492. (doi:10.1002/ar.1092030408)

Palacios F, Tushir JS, Fujita Y \& D'Souza-Schorey C 2005 Lysosomal targeting of E-cadherin: a unique mechanism for the down-regulation of cell-cell adhesion during epithelial to mesenchymal transitions. Molecular and Cellular Biology 25 389-402. (doi:10.1128/MCB.25.1.389402.2005)

Peranen J, Auvinen P, Virta H, Wepf R \& Simons K 1996 Rab8 promotes polarized membrane transport through reorganization of actin and microtubules in fibroblasts. Journal of Cell Biology 135 153-167. (doi:10.1083/jcb.135.1.153)

Pfeffer SR 2007 Unsolved mysteries in membrane traffic. Annual Review of Biochemistry 76 629-645. (doi:10.1146/annurev.biochem.76.061705. 130002)

Raleigh DR, Boe DM, Yu D, Weber CR, Marchiando AM, Bradford EM, Wang Y, Wu L, Schneeberger EE, Shen L et al. 2011 Occludin S408 phosphorylation regulates tight junction protein interactions and barrier function. Journal of Cell Biology 193 565-582. (doi:10.1083/ jcb.201010065)

Robillard KR, Hoque T \& Bendayan R 2012 Expression of ATP-binding cassette membrane transporters in rodent and human Sertoli cells: relevance to the permeability of antiretroviral therapy at the bloodtestis barrier. Journal of Pharmacology and Experimental Therapeutics 340 96-108. (doi:10.1124/jpet.111.186916)

Russell L 1977 Movement of spermatocytes from the basal to the adluminal compartment of the rat testis. American Journal of Anatomy 148 313-328. (doi:10.1002/aja.1001480303)

Schimmoller F, Simon I \& Pfeffer SR 1998 Rab GTPases, directors of vesicle docking. Journal of Biological Chemistry 273 22161-22164. (doi:10.1074/ jbc.273.35.22161)

Siu MK, Wong CH, Lee WM \& Cheng CY 2005 Sertoli-germ cell anchoring junction dynamics in the testis are regulated by an interplay of lipid and protein kinases. Journal of Biological Chemistry $28025029-25047$. (doi:10.1074/jbc.M501049200)

Su W, Mruk DD, Lie PP, Lui WY \& Cheng CY 2012a Filamin A is a regulator of blood-testis barrier assembly during postnatal development in the rat testis. Endocrinology 153 5023-5035. (doi:10.1210/en.2012-1286)

Su W, Wong EW, Mruk DD \& Cheng CY $2012 b$ The Scribble/Lgl/Dlg polarity protein complex is a regulator of blood-testis barrier dynamics and spermatid polarity during spermatogenesis. Endocrinology 153 6041-6053. (doi:10.1210/en.2012-1670)

Takai Y, Sasaki T, Tanaka K \& Nakanishi H 1995 Rho as a regulator of the cytoskeleton. Trends in Biochemical Sciences 20 227-231. (doi:10.1016/ S0968-0004(00)89022-2)

Takai Y, Sasaki T, Shirataki H \& Nakanishi H 1996 Rab3A small GTP-binding protein in $\mathrm{Ca}(2+)$-dependent exocytosis. Genes to Cells 1 615-632. (doi:10.1046/j.1365-2443.1996.00257.x)
Takai Y, Sasaki T \& Matozaki T 2001 Small GTP-binding proteins. Physiological Reviews 81 153-208.

Takaishi K, Sasaki T, Kotani H, Nishioka H \& Takai Y 1997 Regulation of cell-cell adhesion by Rac and Rho small G proteins in MDCK cells. Journal of Cell Biology 139 1047-1059. (doi:10.1083/jcb.139.4.1047)

Vogl AW, Pfeiffer DC, Mulholland D, Kimel G \& Guttman J 2000 Unique and multifunctional adhesion junctions in the testis: ectoplasmic specializations. Archives of Histology and Cytology 63 1-15. (doi:10.1679/ aohc.63.1)

Vogl AW, Vaid KS \& Guttman JA 2008 The Sertoli cell cytoskeleton. Advances in Experimental Medicine and Biology 636 186-211. (doi:10.1007/978-0-387-09597-4_11)

Weber E, Berta G, Tousson A, St John P, Green MW, Gopalokrishnan U, Jilling T, Sorscher EJ, Elton TS, Abrahamson DR et al. 1994 Expression and polarized targeting of a rab3 isoform in epithelial cells. Journal of Cell Biology 125 583-594. (doi:10.1083/jcb.125.3.583)

White J, Johannes L, Mallard F, Girod A, Grill S, Reinsch S, Keller P, Tzschaschel B, Echard A, Goud B et al. 1999 Rab6 coordinates a novel Golgi to ER retrograde transport pathway in live cells. Journal of Cell Biology 147 743-760. (doi:10.1083/jcb.147.4.743)

Wolski KM, Perrault C, Tran-Son-Tay R \& Cameron DF 2005 Strength measurement of the Sertoli-spermatid junctional complex. Journal of Andrology 26 354-359. (doi:10.2164/jandrol.04142)

Wong EW, Mruk DD, Lee WM \& Cheng CY 2008 Par3/Par6 polarity complex coordinates apical ectoplasmic specialization and blood-testis barrier restructuring during spermatogenesis. PNAS 105 9657-9662. (doi:10.1073/pnas.0801527105)

Wong EW, Mruk DD, Lee WM \& Cheng CY 2010 Regulation of blood-testis barrier dynamics by TGF- $\beta 3$ is a Cdc42-dependent protein trafficking event. PNAS 107 11399-11404. (doi:10.1073/pnas.1001077107)

Xia W, Mruk DD, Lee WM \& Cheng CY 2006 Differential interactions between transforming growth factor- $\beta 3 / \mathrm{T} \beta \mathrm{R} 1, \mathrm{TAB} 1$, and CD2AP disrupt blood-testis barrier and Sertoli-germ cell adhesion. Journal of Biological Chemistry 281 16799-16813. (doi:10.1074/jbc.M601618200)

Xiao X, Mruk DD, Lee WM \& Cheng CY 2011 c-Yes regulates cell adhesion at the blood-testis barrier and the apical ectoplasmic specialization in the seminiferous epithelium of rat testes. International Journal of Biochemistry \& Cell Biology 43 651-665. (doi:10.1016/j.biocel.2011. 01.008)

Yan HH, Mruk DD, Lee WM \& Cheng CY 2008 Blood-testis barrier dynamics are regulated by testosterone and cytokines via their differential effects on the kinetics of protein endocytosis and recycling in Sertoli cells. FASEB Journal 22 1945-1959. (doi:10.1096/ fj.06-070342)

Zahraoui A, Joberty G, Arpin M, Fontaine JJ, Hellio R, Tavitian A \& Louvard D 1994 A small rab GTPase is distributed in cytoplasmic vesicles in non polarized cells but colocalizes with the tight junction marker ZO-1 in polarized epithelial cells. Journal of Cell Biology 124 101-115. (doi:10.1083/jcb.124.1.101)

Received in final form 13 February 2013

Accepted 18 February 2013

Accepted Preprint published online 18 February 2013 http://jme.endocrinology-journals.org DOI: 10.1530/JME-13-0011
() 2013 Society for Endocrinology Printed in Great Britain
Published by Bioscientifica Ltd. 